\title{
SYATIIMAH (SWEAR WORDS) AMONG YOUNG LEARNERS: A CASE STUDY OF SMA NEGERI 1 MAKASSAR \\ M. Syaiful ${ }^{1}$, Armien Harry Zainuddin ${ }^{2}$ \\ Faculty of Ushuluddin UIN Alauddin Makassar \\ E-mail: syaifulsimollah@yahoo.com, aerickzainuddin@yahoo.com
}

\begin{abstract}
As the student of SMA Negeri 1 Makassar though of swear words, they truly realized that it is prohibited to express, in certain time and condition. In other cases, they as the student often express it in their daily conversation. The researchers are interested discussing the utterances which contain swear words on the student of SMA Negeri 1 Makassar as one ofspeech community in Makassar. This research aims to determine the category and to find out the intended meaning of the swear words they express.

The researchers use the descriptive qualitative method to describe the mentioned scope of the problem above because this research has the primary data in the form of utterances that contains swear words which provides rich description about its meaning and category. The approach of this research uses pragmatics for the analysis of the context and SPEAKING factors to assist pragmatics in describing the context and find the intended meaning.

As the results, the researcher found that the categories of expressed swearing words in this research are 1. One's Mother in Law (Sundala; Bitch); 2. Certain Game or Animal (Tolo; Bangsat; Goblok/Geblek; Anjing/Anjay/Anjir; Damn; Asu); 3. Sex/Copulative Term (Fuck); 4. Death (Setan); and 5. Excretion (Tai; Telaso; Shit).The intended meaning of swearing words which expressed by the student of SMA Negeri 1 Makassar is mostly based on its connotative meaning, as the expression of startled and anger. Thus, the intended meaning of the expressions are as the normal response of what is being happened, for casual conversation.
\end{abstract}

\section{Keywords: Swear Words, Student, Intended Meaning, Sociology}

\section{A. INTRODUCTION}

The development of language makes several variations of it are established. Those variations include standard and non-standard language. Standard language is a variety of language that is very formal and used in a formal situation, while nonstandard language is a variety of language that is used in an informal situation. Nonstandard language is usually used when someone is talking to a friend, or to a person who is very close to him or her. In other words, non-standard language is the variety of language that is often used when we communicate with others in our daily life. 
One kind of non-standard language which is usually used by the community in interactions with others is called swear words or taboo words. Cursing (swearing) are vile, dirty, rude words that are generally said because of anger, annoyance, or disappointment. Swearing means expressing bad words because of anger, annoyed, disappointed, etc. on someone. Swear words are words that people tend to avoid because they consider that these words to be rude when spoken. ${ }^{1}$ Swear words is one way in which a society expresses its disapproval of certain kinds of behavior which believed to be harmful to its members, either for supernatural reasons or because such behavior is held to violate a moral code. ${ }^{2}$

It is said generally that people who express swear words are considered to be irritated or angry. In another case, on its development, some facts are found that when someone expresses swear words, it is not only to express the expressions of anger or annoyance, but also used to express other expressions, such as when someone wants to express their intimacy or as a greeting, expressions of surprise, and as expressions for satire. ${ }^{3}$

However, swear word is considered as a kind of lower language, gross and disrespectful which is usually uttered by the society thathas a lower educational level.In daily life, it is slightly different as the researcher found.In Makassar, the researcher found that the use of swear words in spoken and written language did not recognize the age limit or the educational level.

As one of the speech communities and as a well-educated community in Makassar, the students of SMA Negeri 1 Makassar are also swear words users. While they in an informal situation, especially when they talk to their friends consciously or not, they usually express swear words in their conversation. It shows that the language usage of students tends to be less good and seemsrude.Seeing from theeducational

${ }^{1}$ David Crystal, The Cambridge Encyclopedia of The English Language, p.172.

${ }^{2}$ Ronald Wardhaugh, An Introduction to Sociolinguistics, p.230.

${ }^{3}$ Purami Sarah Sita Masykur, Bentuk dan Fungsi Umpatan Oleh Siswa SMA Negeri 2 Majene, Sulawesi Barat Dalam Situasi Nonformal, (Journal Skriptorium; 2014), p. 64. 
background, they should not use swear words in speaking, they should be an example for the people in good speech. This shows that there is a discrepancy between what was expected and what actually happened.This is what interests the researcher in investigating the use of swear words among high school students, how they think about the meaning, what is the function and what is the kind of those swear words.

In analyzing the expressed swear words, the researchers use several theories. These theories are pragmatics, SPEAKING theory, and swear words category. Pragmatics is a subfield of linguistics especially semiotics that studies how context contributes to meaning. ${ }^{4}$ Pragmatics is the study of how context affects meaning, such as how sentences are interpreted in certain situations (or the interpretation of linguistic meaning in context). ${ }^{5}$ In this case, the researcher things that pragmatics looks beyond the denotative meaning of aspeech or utterance.Pragmatics is the study of those relations between language and context that are grammaticalized, or encoded in the structure of a language. ${ }^{6}$ Pragmatics considers three things, they are the negotiation of meaning between speaker and listener, the context of the utterance, and the meaning potential of an utterance. ${ }^{7}$

In describing the context of a conversation, when the speaker uses swearing words in conversation, the researcher applies the SPEAKING theory from Hymes. In communication, when a person speaks something, there must be factors that influence his utterance, the factors namely: $(S)$ Setting and Scene of speech, (P) Participants, (E) Ends, (A) Action Sequence, (K) Key, (I) Instrumentalities, (N) Norm, and (G) Genre. ${ }^{8}$

\footnotetext{
${ }^{4}$ https://en.wikipedia.org/wiki/Pragmatics, (accessed on March 7, 2020).

${ }^{5}$ https://ielanguages.com/pragmatics.html, (accessed on March 7, 2020).

${ }^{6}$ Stephen C. Levinson, Pragmatics, p. 9.

7Jenny Thomas, Meaning in Interaction: An Introduction to Pragmatics, p. 12.

${ }^{8}$ D. H. Hymes, Foundations in sociolinguistics: An ethnographic approach, p. 17.
} 


\section{Swear Words among Young Learners: a Case Study of SMA Negeri I Makassar}

Taboo is related to a cultural meaning which is expressed in language. Every society has its way to express its taboo. Taboo exists not only in terms of words but also in terms of gestures, pictures, attitudes, behavior, and so on. Taboo words are those that are to be avoided entirely or at least avoided in mixed company or polite company. ${ }^{9}$ Typical examples involved common swear words such asDamn! or Shit!. Taboo words occur in most of all languages, many people avoid using taboo in a formal situation. there are 8 categories of taboo words namely: One's Mother in Law, Certain Game or Animal, Sex/Copulative Term, Death, Bodily Function/Human Genitals term, Excretion, Religious Matter, and The Left Hand. ${ }^{10}$

\section{B. METHOD}

This type of research uses qualitative method, because it describes the data using narrative description rather than using statistics. One of the characteristic of qualitative research is without using numerical analysis. The data also concerned appear in words rather than in numbers. The detailed approach to the description is necessary to obtain a complete understanding of the setting and to accurately reflect the complexity of the expressed swearing words. The researcher uses qualitative research also because this research has the primer data in the form of utterances which is provide rich description and analysis of the data.

The methodology of collecting data are done through two ways, library research and field research. Library resesarch is done by reading relevant textbooks, published articles, theses, and also by searching related studies on the internet. Field research is done through direct interview and note-taking. The researcher take a voice recording and write a note while interviewing the respondents. The researcher randomly selected the respondents In this study. The researcher limits the object of interview to three students each grade as the source of data.

\section{DISCUSSION}

\section{The Categories}

\footnotetext{
${ }^{9}$ Ronald Wardhaugh, An Introduction to Sociolinguistics, p. 229.

${ }^{10}$ Ronald Wardhaugh, An Introduction to Sociolinguistics, p. 230.
} 
As the data obtained that the expressed swear words not only from English but Indonesian and Makassarese too. Thus, for Makassarese swear words the researcher will find out the equivalent of its meaning in Indonesian first then in English. The obtained data also shows that there are several modified swearing words be expressed by the student like geblek, anjir, and anjay. For the modified swear words, the researcher will show it on table 2.

Table 1

\begin{tabular}{|c|c|c|}
\hline No. & Expression & Swearing Words \\
\hline 1. & "Telaso, terlambat ka masuk!" & Telaso \\
\hline 2. & "Tolo inie... para dia ji berkelahi!" & Tolo \\
\hline 3. & "Shit... lupa ka kerja tugas bro." & Shit \\
\hline 4. & $\begin{array}{l}\text { "Tadi malam kemana ko? Ke rumahmu ka tadi malam mau } \\
\text { jemput ko tapi tidak ada ko setan." }\end{array}$ & Setan \\
\hline 5. & "We anjing, jangan ko ganggu ka dulu." & Anjing \\
\hline 6. & "Mau ko nebeng apa anjir, na naik gojek ka pulang." & Anjir \\
\hline 7. & $\begin{array}{l}\text { "Beh... bro kenapa ko lupa bawa tugasku yang ko pinjam } \\
\text { semalam? Mau diperiksa sebentar kodong.. Sundala!" }\end{array}$ & Sundala \\
\hline 8. & "Tidak mengerti sekali ini anak e... telaso. Orang sibuk" & Telaso \\
\hline 9. & "Sundala itu anak!" & Sundala \\
\hline 10. & "Farid cepat mko anjir, terlambat mki ini." & Anjir \\
\hline 11. & "Telaso! ditilang ka Polantas tadi malam di jalan veteran." & Telaso \\
\hline 12. & "Jangan nangis bro, masih banyak ji bitch. hahaha" & Bitch \\
\hline 13. & "We... Pulpenku setan, mau ka menulis." & Setan \\
\hline 14. & $\begin{array}{l}\text { "Pinjam dulu uangmu bro, jatuh tadi uangku di jalan, } \\
\text { sundala." }\end{array}$ & Sundala \\
\hline 15. & "Fuck...hahahah. Saya tahu ji kalau bohong-bohong ko." & Fuck \\
\hline 16. & "Makanya belajar ko goblok... Hahaha" & Goblok \\
\hline 17. & "Damn... cantiknya itu anak kelas sebelas." & Damn \\
\hline
\end{tabular}


Swear Words among Young Learners: a Case Study of SMA Negeri I Makassar

\begin{tabular}{|l|l|c|}
\hline 18. & "Bangsat ini anak... kentut baru orang sementara makan." & Bangsat \\
\hline 19. & "Anjir... terlambat sedeng masuk kelas." & Anjir \\
\hline 20. & "Gara-gara terlambat ka tadi masuk, disuruh ka bersihkan \\
WC sendiri. Bangsat... bangsat." & Bangsat \\
\hline 21. & "Sini pulpenku asu..." & Asu \\
\hline 22. & "tunggu ka... we, sama-sam ki pergi tai." & Tai \\
\hline 23. & "Bantu ka dulue angkat ini, berat ki ini telaso." Telaso \\
\hline 24. & "Cengeng sekali, tai." & Tai \\
\hline
\end{tabular}

Table 2.

\begin{tabular}{|l|c|c|c|}
\hline No. & English & Indonesian & Makassarese \\
\hline 1. & Bitch & Tai & Tolo \\
\hline 2. & Shit & Setan & Sundala \\
\hline 3. & Fuck & Goblok & Telaso \\
\hline 4. & Damn & Anjing & Asu \\
\hline 5. & - & $\begin{array}{r}\text { Geblek } \\
\text { (modified from goblok) }\end{array}$ & - \\
\hline 6. & - & $\begin{array}{r}\text { Anjay } \\
\text { (modified from anjing) }\end{array}$ & \\
\hline 7. & - & Anjir & - \\
\hline 8. & & (modified from anjing) & \\
\hline
\end{tabular}

a. Tai e.g: "cengeng sekali, tai"

The term Tai or Tahi is an Indonesian word for (n) -feces/shit/excretion. From WordWeb Dictionary the researcher found several meanings of it, including 1) Solid excretory product evacuated from the bowels; 2) Obscene word for unacceptable behavior; 3) An interjection, Exclamation of annoyance. ${ }^{11}$ From

${ }^{11}$ WordWeb Version 4.0 (offline dictionary application for mobile phone). 
www.urbandictionary.com the researcher found for shit, 1) a slang term to describe an address for people who are stupid or ridiculous; 2) A slang term means an insult describing that person as a poop; and 3) A slang term for a useless thing or person. ${ }^{12}$

According to the swear words category by Ronald Wardhaugh, this term belongs to "Excretion". The researcher categorized it into Excretion category based on explanation the category that it is excrement that came out from our body. This explanation is following the meaning of Tai as a solid excretory product evacuated from the bowels.

b. Setan e.g. "Tadi malam darimanako... kucari tidak ada? Darika rumahmu setan"

The term Setan is an Indonesian word for (n) -ghost/heck/satan. From WordWeb Dictionary the researcher found several meanings of it, including 1). The visible disembodied soul of a dead person; 2). A mental representation of some haunting experience; and 3). (Judeo-Christian and Islamic religions) chief spirit of evil and adversary of God; tempter of mankind; master of hell. ${ }^{13}$ From www.urbandictionary.com the researcher found for ghost including 1). Government intelligence agents in 1960's America; 2). The discarnate soul of a deceased human being or animal still occupying the physical realm; and 3). An interjection used to express amazement at some unlikely act or strange object. ${ }^{14}$

According to the swear words category by Ronald Wardhaugh, this term belongs to "Death". The researcher categorized it into Death category based on the explanation of the category that it is related to death, referring to something supernatural and also related to afterlife. This explanation is in accordance with the meaning of Setan as a supernatural being.

\footnotetext{
${ }^{12}$ https://www.urbandictionary.com/define.php?term=shit (accessed on May 12, 2020 at ??:??)

${ }^{13}$ WordWeb Version 4.0 (offline dictionary application for mobile phone).

${ }^{14}$ https://www.urbandictionary.com/define.php?term=Ghost (accessed on May 12, 2020).
} 


\section{Swear Words among Young Learners: a Case Study of SMA Negeri I Makassar}

\section{c. Tolo e.g. "Tolo inie... para dia ji berkelahi!"}

The term tolo is a Makassarese term that comes from Indonesian word Tolol. This word stands for (adj.) -stupid/fool/dumb/; (n) -moron. From WordWeb Dictionary the researcher found several meanings of it, including 1 ). Lacking or marked by lack of intellectual acuity; 2). Lacking intelligence; and 3). A person of subnormal intelligence. ${ }^{15}$ While from www.urbandictionary.com, the researcher found for stupid including 1). Lacking ordinary quickness and keenness of mind; and 2). Annoying or irritating; troublesome; 3). Name for a person,any type of person; and 4) a slang term that can be used in anger or friendship. ${ }^{16}$

According to the swear words category by Ronald Wardhaugh, this term belongs to "Certain Game or Animal". The researcher categorized it into Certain Game or Animal category based on the explanation of the category that it related to behaviors of animal which is lack of intelligence than humans. This explanation is in accordance with the meaning of Tolo as a lack of intellectual.

\section{d. Bangsat e.g. "Bangsat ini anak... kentut baru orang sementara makan."}

The term bangsatis an Indonesian word for ( $n$ ) -bastard/scoundrel/rotter. From WordWeb Dictionary the researcher found several meanings of it, including 1). A child with parents that are not married to each other; 2 ). Insulting term of address for people who are stupid, irritating or ridiculous; 3). Something large and impressive, especially when difficult or unpleasant to manage; and 4). A person who is deemed to be despicable or contemptible. ${ }^{17}$ While from www.urbandictionary.com the researcher found for bastard including 1). A term used to describe someone who disregards other people in pursuit of their

\footnotetext{
${ }^{15}$ WordWeb Version 4.0 (offline dictionary application for mobile phone).

${ }^{16} \mathrm{https}$ ://www.urbandictionary.com/define.php?term=stupid (accessed on May 12, 2020).

${ }^{17}$ WordWeb Version 4.0 (offline dictionary application for mobile phone).
} 
own self-interest; 2). A smelly bedbug; 3). A dishonest or unscrupulous person; a rogue; and 4). Refers to the second rate of Spanish Sack of wines. ${ }^{18}$

According to the swear words category by Ronald Wardhaugh, this term belongs to "Certain Game or Animal". The researcher categorized it into Certain Game or Animal category that it is related to behavior of animal which is had sexual intercourse out of wedlock. This explanation is in accordance with the meaning of Bangsat as A child born out of wedlock.

\section{e. Goblok e.g. "Makanya belajar ko goblok... Hahaha"}

The term goblok is an Indonesian word for (adj.) - stupid/fool/dumb. This term is equal in meaning with Tolol and Bodoh. From WordWeb Dictionary the researcher found several meanings of it, including 1). Lacking or marked by lack of intellectual acuity; 2). Lacking intelligence; and 3). A person of subnormal intelligence. ${ }^{19}$ While from www.urbandictionary.com the researcher found for stupid including 1). Lacking ordinary quickness and keenness of mind; and 2). Annoying or irritating; troublesome; and 3). Name for a person,any type of person; and 4). A slang term that can be used in anger or friendship. ${ }^{20}$

According to swear words category by Ronald Wardhaugh, this term belongs to "Certain Game or Animal". The researcher categorized it into Certain Game or Animal category based on the explanation of the category that it is related to behaviors of animal which is lack of intelligence than humans. This explanation is in accordance with the meaning of Goblok as a lack of intelligence.

\section{f. Anjing e.g. "Deh, banyak salah jawabanku... anjing."}

The term anjingis an Indonesian word for ( $n$ ) -dog. From WordWeb Dictionary the researcher found several meanings of it, including 1). A member of the genus Canis (probably descended from the common wolf) that has been domesticated by man since prehistoric times; occurs in many breeds; 2). A dull,

\footnotetext{
${ }^{18} \mathrm{https}: / /$ www.urbandictionary.com/define.php?term=bastard (accessed on May 12, 2020)

${ }^{19}$ WordWeb Version 4.0 (offline dictionary application for mobile phone).

${ }^{20} \mathrm{https}$ ///www.urbandictionary.com/define.php?term=stupid (accessed on May 12, 2020).
} 
unattractive, unpleasant girl or woman; and 3). Someone who is morally reprehensible. ${ }^{21}$ While from www.urbandictionary.com, the researcher found for dog including 1). An informal term for a man; 2). Your best friend; and 3). Human best friend; and 4). An obscene term used to describe an enraging situation. ${ }^{22}$

According to swear words category by Ronald Wardhaugh, this term belongs to "Certain Game or Animal". The researcher categorized it into Certain Game or Animal category based on the explanation of the category that it is related to animal and its behaviors. This explanation is in accordance with the meaning of Anjing as a four-legged creature (member of the genus Canis).

\section{g. Sundala e.g. "Sundala itu anak!"}

The term sundala is a Makassarese word which derives from Malayan word Sundal means(n) - perempuan jalang. In English, this word stands for (n) -bitch. From WordWeb Dictionary the researcher found several meanings of it, including 1). Female of any member of the dog family; 2). An unpleasant difficulty; and 3). A person (usually but not necessarily a woman) who is thoroughly disliked. ${ }^{23}$ While from www.urbandictionary.com, the researcher found for bitch including 1). A vulgar slang term for slut; and 2). A women who had many affairs with more of one man. ${ }^{24}$

According to swear words category by Ronald Wardhaugh, this term belongs to "One's Mother in Law". The researcher categorized it into One's Mother in Law category based on the explanation of the category that this term is used to describe a woman who had affair with many parnerts. This explanation is in accordance with the meaning of Sundala as slut.

h. Bitch e.g. "Jangan nangis bro, masih banyak ji bitch. hahah"

\footnotetext{
${ }^{21}$ WordWeb Version 4.0 (offline dictionary application for mobile phone).

${ }^{22}$ https://www.urbandictionary.com/define.php?term=dog (accessed on May 12, 2020).

${ }^{23}$ WordWeb Version 4.0 (offline dictionary application for mobile phone).

${ }^{24}$ https://www.urbandictionary.com/define.php?term=bitch (accessed on May 12, 2020).
} 
The term bitchis an English word. Old usage of this term is for a female dog, but later became an euphemism for slut in the 1800's America. From WordWeb Dictionary the researcher found several meanings of it, including 1). Female of any member of the dog family; 2). An unpleasant difficulty; and 3). A person (usually but not necessarily a woman) who is throughly dislike. ${ }^{25}$ While from www.urbandictionary.com, the researcher found for bitch including 1). A vulgar slang term for slut; and 2). A women who had many affair with more of one man. ${ }^{26}$

According to swear words category by Ronald Wardhaugh, this term belongs to "One's Mother in Law". The researcher categorized it into One's Mother in Law category based on the explanation of the category that this term is used to describe a woman who had affair with many partners. This explanation is in accordance with the meaning of Bitch as bad woman (slut) and as a female dog that hits and runs by any male dog.

\section{i. Telaso e.g. "Telaso! ditilang ka Polantas tadi malam di jalan veteran."}

The term telaso comes from Tailaso/Tahi laso. This is a Makassarese word, coarse term to insult someone or something. The researcher did not found any equal term in English of it, but literally this term means ( $n$ ) - penial excrement/penis' filth. In Makassar, this word is usually used to express anger, pique, or regret.

According to swear words category by Ronald Wardhaugh, this term belongs to "Excretion". The researcher categorized it into Excretion category based on the explanation of the category that this term is one of excrement of man's body. This explanation is in accordance with the meaning of Telaso as excrement of the penis.

j. Shit e.g. "Shit... lupa ka kerja tugas bro."

The term shit is an English word. This term usually uses as the expression of surprise. From WordWeb Dictionary the researcher found several meanings of it,

${ }^{25}$ WordWeb Version 4.0 (offline dictionary application for mobile phone).

${ }^{26} \mathrm{https} / / /$ www.urbandictionary.com/define.php?term=bitch (accessed on May 12, 2020). 
including 1). Solid excretory product evacuated from the bowels; 2). Obscene word for unacceptable behavior; 3). An interjection, Exclamation of annoyance. ${ }^{27}$ While from www.urbandictionary.com the researcher found for shit including 1). A slang term to describe an address for people who are stupid or ridiculous; 2 ). A slang term means an insult describing that person as a poop;3). A slang term for useless thing or person. ${ }^{28}$

According to swear words category by Ronald Wardhaugh, this term belongs to "Excretion". The researcher categorized it into Excretion category based on the explanation of the category that it is excrement which came out from our body. This explanation is in accordance with the meaning of Shit as a fecal matter evacuated from the bowels.

k. Asu e.g. "Sini pulpenku asu..."

The term asu is one of the coarse exclamations in South Sulawesi. All of the regions and ethnic groups in South Sulawesi know and use this term in exclamation. This term is equal in meaning with (n) -dog. From WordWeb Dictionary the researcher found several meanings of it, including 1). A member of the genus Canis (probably descended from the common wolf) that has been domesticated by man since prehistoric times; occurs in many breeds; 2). A dull, unattractive, unpleasant girl or woman; and 3). Someone who is morally reprehensible. ${ }^{29}$ While from www.urbandictionary.com, the researcher found including 1). An informal term for a man; 2). Your best friend; and 3). Human best friend; and 4). an obscene term used to describe an enraging situation. ${ }^{30}$

According to swear words category by Ronald Wardhaugh, this term belongs to "Certain Game or Animal". The researcher categorized it into Certain Game or Animal category based on the explanation of the category that it is

\footnotetext{
${ }^{27}$ WordWeb Version 4.0 (offline dictionary application for mobile phone).

${ }^{28}$ https://www.urbandictionary.com/define.php?term=shit (accessed on May 12, 2020).

${ }^{29}$ WordWeb Version 4.0 (offline dictionary application for mobile phone).

${ }^{30} \mathrm{https}: / /$ www.urbandictionary.com/define.php?term=dog (accessed on May 12, 2020).
} 
related to animal and its behaviors. This explanation is in accordance with the meaning of Asu as a four-legged creature (a member of the genus Canis). Table 3.

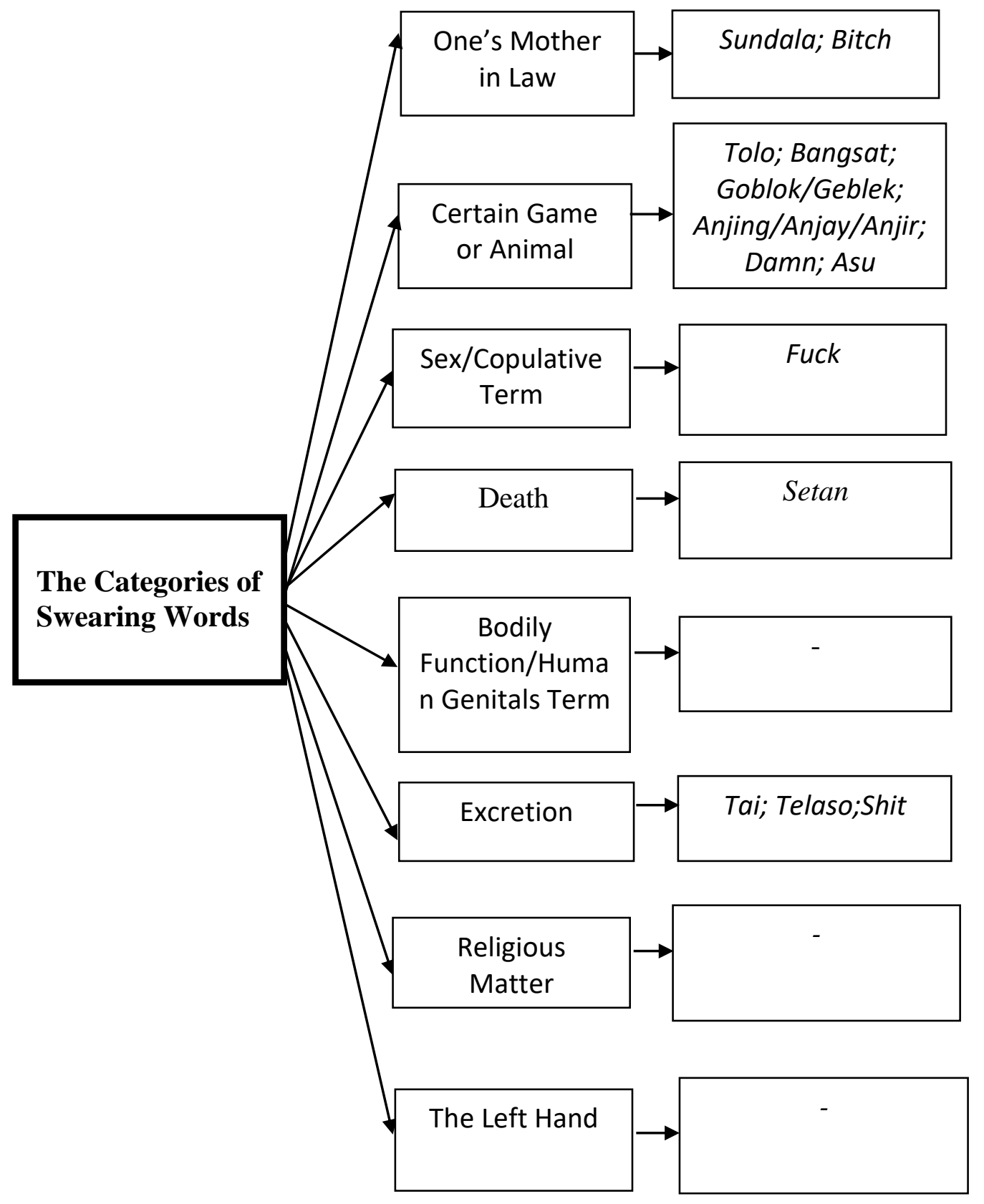


2. Their Utterances and Its Meaning

a. "Cengeng sekali, tai."

\begin{tabular}{|l|l|}
\hline Corpus & Cengeng sekali tai \\
\hline Morphem break & Cengeng sekali tai \\
\hline Gloss & Crybaby very feces \\
\hline Part of speech & Adjective, Adverb, Noun \\
\hline Free translation & Why are you so whiny \\
\hline
\end{tabular}

This sentence was expressed by Wandi, $12^{\text {th }}$ grader.Addressed to Miranda and Agus as the listeners. The setting while he expresses it was at school, precisely in Wandi's class. The scene of this expression starts when Wandi and Agus playing mobile game in their classroom. At the time, Miranda came with her tears because she just broke with her boyfriend. She came to Wandi's classroom to tell him about her feeling, about what she feels. They werea little bit annoyed by Miranda's appearance.The norm that applied in this conversation is the friendship norm. In this conversation, the relationship between Wandi, Agus, and Miranda is aclose friend.

When Wandi express it his manner was easy, although Miranda's appearance was annoying him and Agus. The tone of his voice is normal, also his spirit, normal as usual. The information about this occurrence implies the researcher that they are in a casual conversation not in a serious. This conversation is a close friend conversation in a melancholy situation. According to discussions about the meaning, occurrence, and the context above, the researcher concludes that the intended meaning of term taiin this expression is the same as its connotative meaning of it, which is an obscene word for unacceptable behavior. Then as the whole intended meaning of this expression, the researcher concludes that Wandi was want to tell Miranda easily that "do not be so whiny, there are a thousand boys out there." 
b. "Tadi malam kemana ko? Ke rumahmu ka mau jemput ko setan, tapi tidak ada ko."

\begin{tabular}{|l|l|}
\hline Corpus & $\begin{array}{l}\text { Tadi malam kemana ko? Ke rumahmu ka mau } \\
\text { jemputko setan tapi tidak ada ko }\end{array}$ \\
\hline Morphem break & $\begin{array}{l}\text { Tadi malam kemana ko? Ka mauka ke rumahmu } \\
\text { jemputko setan tapi tidak ada ko }\end{array}$ \\
\hline Gloss & $\begin{array}{l}\text { Last night where you to house your I want pick you } \\
\text { evil but no there you }\end{array}$ \\
\hline Part of speech & $\begin{array}{l}\text { Adverb, adverb, noun, preposition, noun, pronoun, } \\
\text { noun, noun, verb, pronoun, adjective, conjunction, } \\
\text { noun, adverb, noun }\end{array}$ \\
\hline Free translation & $\begin{array}{l}\text { Where have you been last night? I am about to pick } \\
\text { you up }\end{array}$ \\
\hline
\end{tabular}

This sentence was expressed by Fuad, $12^{\text {nd }}$ grader. Addressed to Farid as the listener. The setting while he expresses it was at school, precisely at the parking lot of the school. The scene of the expression above is when Fuad just came to school and parking his motorcycle in the parking lot. Soon after Fuad parking his motorcycle Farid approached him and laughing slightly. This occurrence happens because when Fuad came to Farid's home at night to pick him up for an appointment they have made before, but Farid forgot the appointment. Fuad gets angry because of this. The norm that applied in this conversation is the friendship norm. In this conversation, there is a relationship between Fuad and Farid. The kind of relationship between them isa close friend.

When Fuad express it his manner is serious, although Farid was laughing a little and fell sorry. The tone of his voice is normal, but his spirit was peevish. The information about this occurrence implies the researcher that they are in serious 
condition. This conversation is a close friend conversation in annoying situation. According to discussions about the meaning, occurrence and context above the researcher conclude that the intended meaning of term setan in this expression is the same as its connotative meaning, which is an interjection used to express amazement at some unlikely act or strange object.As the whole intended meaning of this expression, the researcher concludes that Fuad was want to tell Farid angrily that "why did you forget the appointment?".

c. "Tolo inie... para dia ji berkelahi!"

\begin{tabular}{|l|l|}
\hline Corpus & Tolo ini para dia ji berkelahi \\
\hline Morphem break & Tolo ini para dia ji berkelahi \\
\hline Gloss & Stupid this fellow he only fight \\
\hline Part of speech & Adjecctive, pronoun, noun, pronoun, adjective, verb \\
\hline Free translation & $\begin{array}{l}\text { You guys are so stupid, I can't believe you fight each } \\
\text { other }\end{array}$ \\
\hline
\end{tabular}

This sentence is expressed by lksan, a $11^{\text {th }}$ grader. Addressed to Wahyu and Andi as the listeners. The setting while he expresses it was in school, precisely in front of his classroom. The scene of the expression above is when Iksan gets his lunch at the school's canteen. At the time, while he lunch, one of his classmates came and approached him rushly, named Syaiful. Syaiful told him that Wahyu and Andi were just fighting in front of their classroom. Iksan was surprised. Soon, Iksan finished his lunch and go to meet Wahyu and Andi. He was disappointed and angry because two of his close friends were fighting. The norm that applied in this conversation is the friendship norm. In this conversation, the relationship between Iksan, Wahyu, and Andi is a close friend.

When Iksan expresses it his manner was serious, and the condition at the time was strain. The tone of his voice was high, his spirit was emotional. The 
information about this occurrence explains the researcher that they are in a serious conversation. This conversation is a close friend conversation in an annoying situation. According to discussions about the meaning, occurrence, and context above the researcher conclude that the intended meaning of term tolo in this expression is the same as its connotative meaning, which is a slang term that can be used in anger or friendship. As the whole intended meaning of this expression, the researcher concludes that Iksan was want to tell Wahyu and Andi angrily that "close friends did not fight of each other."

d. "Bangsat ini anak... kentut baru orang sementara makan."

\begin{tabular}{|l|l|}
\hline Corpus & $\begin{array}{l}\text { Bangsatnya ini anak kentut baru orang sementara } \\
\text { makan }\end{array}$ \\
\hline Morphem break & $\begin{array}{l}\text { Bangsat ini anak kentut baru orang sementara } \\
\text { makan }\end{array}$ \\
\hline Gloss & Scoundrel this kid fart new people while eat \\
\hline Part of speech & $\begin{array}{l}\text { Noun, pronoun, noun, noun, adjective, noun } \\
\text { conjunction, verb }\end{array}$ \\
\hline Free translation & So damn! You get fart while I am eating \\
\hline
\end{tabular}

This sentence is expressed by Septian, $a 10^{\text {th }}$ grader. Addressed to Anwar, Widya, Fauzi, and Akbar as the listeners. The setting while he expresses it was in school, precisely in the canteen. The scene of the expression above is when all of them in the canteen to get their lunch. At the time there are no more students in the canteen except them, they were late to take their lunch. While they were lunch, a fart's sound heard, bad smell fill up their nose. Soon, several of them complaining, where the rest were laughing. Certainly, all of them feeling disgusted by that fart. It was Anwar who farts while they lunch. Soon after Septian knows that it was Anwar, he angry and rebukes Anwar. The norm that 
applied in this conversation is the friendship norm. In this conversation, the relationship between Widya, Anwar, Fauzi, and Akbar is a close friend.

When Septian expresses it his manner was serious. At the moment he was peevish. The tone of his voice was high, his spirit was irritated. He thinks that it is an irreverent behavior. The information about this occurrence implies the researcher that they are in a serious conversation. This conversation is a close friend conversation in an annoying situation. According to discussions about the meaning, occurrence and context above the researcher conclude that the intended meaning of term bangsat in this expression is the same as its connotative meaning, which is "insulting term of address for people who are stupid, irritating or ridiculous." Then as the whole intended meaning of this expression, the researcher concludes that Septian was want to tell Anwar angrily that "such a disgust person, why did you so impolite?".

e. "Makanya belajar ko goblok... Hahaha"

\begin{tabular}{|l|l|}
\hline Corpus & Makanya belajarko goblok hahaha \\
\hline Morphem break & $\begin{array}{l}\text { Maka+nya (inflectional morpheme) belajar ko } \\
\text { goblok hahaha }\end{array}$ \\
\hline Gloss & Thus learn you stupid (laughing) \\
\hline Part of speech & Conj., verb, pronoun, adjective, verb \\
\hline Free translation & Therefore, you should learn a lot, stupid! \\
\hline
\end{tabular}

This sentence is expressed by Kiki, $11^{\text {th }}$ grader. Addressed to Aswan as the listener. The setting while he expresses it was at school, precisely in front of their classroom. The scene of the expression above is when all of them have finished doing the Chemistry exam. They all talking to each other about the chemistry exam that they just attended. At the time, they discuss the answer and their exam result. While they discuss, Aswan complains about his exam result, that his score was disappointing. Kiki laughing, she feels that it was funny and soon reply 
the Aswan's complaint. The norm that applied in this conversation is the friendship norm. In this conversation, the relationship between Kiki, Aswan, and Zulfikar is a close friend.

When Kiki express it her manner was easy. At the time she was sarcastic. The tone of her voice was normal, her spirit also. She thinks that it is a funny case, so she mocking upon Aswan. The information about this occurrence implies the researcher that they are in a casual conversation. This conversation is a close friend conversation in an amusing situation. According to discussions about the meaning, occurrence, and context above the researcher concludes that the intended meaning of term Goblok in this expression is the same as its denotative meaning, which is "lack of intellectual acuity." As the whole intended meaning of this expression, the researcher concludes that Kiki was want to tell Aswan easily that "you should learn before the test begins."

f. "Deh, banyak salah jawabanku... anjing."

\begin{tabular}{|l|l|}
\hline Corpus & Deh banyak sekali salah jawabanku anjing \\
\hline Morphem break & Deh banyak salah jawaban ku anjing \\
\hline Gloss & Oh many wrong answer me dog \\
\hline Part of speech & $\begin{array}{l}\text { Exclamation, adjective, adjective, noun, pronoun, } \\
\text { noun }\end{array}$ \\
\hline Free translation & Oh my god, I got a lot of wrong answer \\
\hline
\end{tabular}

This sentence is expressed by Aswan,an $11^{\text {th }}$ grader.Addressed to Kiki and Zulfikar as the listeners. This expression was the fragment of Kiki's expression ("Makanya belajar ko goblok... Hahaha."). The setting while he expresses it was at school, precisely in front of their classroom. The scene of the expression above is when all of them have finished doing the Chemistry exam. This occurrence happens when they all talking to each other about the chemistry exam that they 
just attended. At the time, they discuss the answer and their exam result. Aswan complain about his exam result, his score was disappointing him, In this conversation, Aswan was complaining about his test result. The norm that applied in this conversation is the friendship norm. In this conversation, the relationship between Kiki, Aswan, and Zulfikar is a close friend.

When Aswan express "Deh, banyak salah jawabanku... anjing." his manner was serious. At the moment he was cranky. The tone of his voice was low, his spirit was melancholy. He thinks that the exam will run properly, but in fact, it is not. The information about this occurrence implies the researcher that they are in a casual conversation. This conversation is a close friend conversation in a melancholy situation. According to discussions about the meaning, occurrence, and context above the researcher conclude that the intended meaning of term anjing in this expression is the same as its connotative meaning, which is an obscene term used to describe an enraging situation.As the whole intended meaning of this expression, the researcher concludes that Aswan was want to tell Kiky and Zulkifli that "he was lament because did not learn much about the test."

g. "Sundala itu anak!"

\begin{tabular}{|l|l|}
\hline Corpus & Sundala itu anak \\
\hline Morphem break & Sundala Itu Anak \\
\hline Gloss & Son of a bitch that kid \\
\hline Part of speech & Adjective, Conj., Noun \\
\hline Free translation & He is so shitty \\
\hline
\end{tabular}

This sentence is expressed by Rezki, a $12^{\text {th }}$ grader. Addressed to Fariz while he speaks with Ryan. The setting while he expresses it was at school, precisely in the basketball field. The scene of the expression above is soon after Rezky has finished his basketball training. This occurrence happens when Rezky 
goes for his basketball training, he entrusts and parks his motorbike in Ryan's home because the basketball field is near from Ryan's home. At the time, after finishing his training, Rezki asks Ryan about his motorbike because he wants to go back home soon. Ryan tells that his motorbike was used by one of their friends named Fariz while Rezki training, Rezki was angry and peevish about that, because he was asked by his father to go back home soon. The norm that applied in this conversation is a friendship norm. The friendship norm applied to Rezky as the speaker and Ryan as the interlocutor. In this conversation the relationship between Rezky and Ryan they are as a close friend.

When Rezki expresses ithis manner was serious. At the moment he was annoyed. As we can see from the chat, Rezki looks angry. The information about this occurrence implies the researcher that they are in a serious conversation. This conversation is a close friend conversation in an irritating situation. According to discussions about the meaning, occurrence, and context above the researcher concludes that the intended meaning of term sundala in this expression is the same as its connotative meaning, which is a term for a person who is thoroughly disliked.As the whole intended meaning of this expression, the researcher concludes that Rezki was want to tell Ryan that "he was totally angry toward Fariz."

h. "Jangan nangis bro, masih banyak ji bitch. hahah"

\begin{tabular}{|c|c|}
\hline Corpus & Jangan nangis bro masih banyak ji bitch hahaha \\
\hline Morphem break & Jangan nangis bro masih banyak ji bitch hahaha \\
\hline Gloss & Don't cry brother still many only bitch hahaha \\
\hline Part of speech & $\begin{array}{l}\text { Contraction, Verb, noun, adverb, adjective, } \\
\text { adjective, adverb, noun, verb }\end{array}$ \\
\hline Free translation & $\begin{array}{l}\text { You should not cry bro, there are still many girls out } \\
\text { there (laughing) }\end{array}$ \\
\hline
\end{tabular}


This sentence is expressed by Ilham Saputra, a $10^{\text {th }}$ grader. Addressed to Alfian as the listener.The setting while he expresses it was in a cafe, after school hour. The scene of the expression above is when Alfian called Ilham to hang out together. Alfian needs a friend to talk about what he feels. Alfian aimed to talk to Ilham about his relationship with his girlfriend called Nur Alifiah. At the time, Alfian sad because she just broke up with his girlfriend. He told Ilham that he just broke up. As Ilham hear it, he responded casually and laughed slightly.

When Ilham express it his manner was easy. At the moment he was mediocre. The tone of his voice was normal, his spirit was calm. Alfian was sad at the time. The information about this occurrence implies the researcher that they are in a casual conversation. This conversation is a close friend conversation in a melancholy situation. According to discussions about the meaning, occurrence, and context above the researcher concludes that the intended meaning of term Bitch in this expression is the same as its connotative meaning, which is "a vulgar slang term for slut." As the whole intended meaning of this expression, the researcher concludes that Alfian was want to tell Ilham that "do not be sad."

i. "Telaso! ditilang ka Polantas tadi malam di jalan veteran."

\begin{tabular}{|l|l|}
\hline Corpus & $\begin{array}{l}\text { Telaso! Ditilang ka Polantas tadi malam di jalan } \\
\text { veteran }\end{array}$ \\
\hline Morphem break & $\begin{array}{l}\text { Telaso di tilang ka polentas tadi malam di jalan } \\
\text { veteran }\end{array}$ \\
\hline Gloss & $\begin{array}{l}\text { Penial-excrement in fined me police last night on } \\
\text { street veteran }\end{array}$ \\
\hline Part of speech & $\begin{array}{l}\text { Noun, preposition, verb, noun, adjective, noun, } \\
\text { adverb, noun (street name) }\end{array}$ \\
\hline Free translation & Damn! I got fined by the police one the veteran \\
\hline
\end{tabular}




\begin{tabular}{|l|l|}
\hline & street last night \\
\hline
\end{tabular}

This sentence is expressed by Fikri, a10 ${ }^{\text {th }}$ grader.Addressed to Riswan, Hadi, and Syukran as the listeners. The setting while he expresses it was at Syukran's Home. The scene of the expression above is when all of them heading to Syukran's home to finish their school task after school. Each of them riding their own motorbike. They were separated while on the way to Syukran's home. At the time, Fikri was the last person who arrived at Syukran's home. He got ticketed by the police because he was breaking the traffic light. The norm that applied in this conversation is the friendship norm. In this conversation, the relationship between Ilham and Alfian is a close friend.

When Fikri expresses it his manner was serious. At the moment he was peevish. The tone of his voice was high, his spirit was annoyed. Fikri was pale a while thinking of his ticket. The information about this occurrence implies the researcher that they are in a serious conversation. This conversation is a close friend conversation in an annoying situation. According to discussions about the meaning, occurrence, and context above the researcher concludes that the intended meaning of term Telaso in this expression is the same as its connotative meaning, which is "coarse term to insult someone or something."As the whole intended meaning of this expression, the researcher concludes that Fikri was want to tell Riswan, Hadi, and Syukran that "he was upset by that occasion."

j. "Shit... lupa ka kerja tugas bro."

\begin{tabular}{|l|l|}
\hline Corpus & Shit lupa ka kerja tugas bro \\
\hline Morphem break & Shit lupa ka kerja tugas bro \\
\hline Gloss & Shit forgot me do task brother \\
\hline Part of speech & Noun verb pronoun verb noun noun \\
\hline Free translation & Shit! I forgot to do my homework \\
\hline
\end{tabular}


This sentence is expressed by Rezki Annas, a $12^{\text {th }}$ grader. Addressed to his seatmate as the listener, named Yudi. The setting while he expresses it was in their classroom, exactly on their seat. The scene of the expression above is when all of the students were asked by their teacher about their homework that has been given last week. This occurrence happens when Rezki and Yudi open their bag and look for the book. At the time, Rezki was opened his book and find nothing, he forgetsto do his homework at night because he was watching a football match till late at night. The norm that applied in this conversation is the friendship norm. In this conversation, the relationship between Rezki and Yudi is a close friend.

When Rezki expresses it his manner was serious. At the moment he felt guilty. The tone of his voice was normal, his spirit was depressed. He thinks that he will get a punishment. The information about this occurrence implies the researcher that they are in a serious conversation. This conversation is a close friend conversation in a guilty situation. According to discussions about the meaning, occurrence, and context above the researcher concludes that the intended meaning of term Shit in this expression is the same as its connotative meaning, which is "obscene word for unacceptable behavior." As the whole intended meaning of this expression, the researcher concludes that Rezki was want to tell Yudi that "he forgot to do his homework and regret it."

k. "Sini pulpenku asu..."

\begin{tabular}{|l|l|}
\hline Corpus & Sini pulpenku asu \\
\hline Morphem break & Sini pulpen ku asu \\
\hline Gloss & Here pen me dog \\
\hline Part of speech & Adverb noun pronoun noun \\
\hline Free translation & Give me back my pen, shit! \\
\hline
\end{tabular}


This sentence is expressed by Rahmat, $11^{\text {th }}$ grader. Addressed to Wahyu as the listener. The setting while he expresses it was in school, precisely in their classroom, and the time was morning. The scene of the expression above is when they want to do a task from their teacher. Wahyu was in front of Rahmat seat. At the time, Rahmat was in hurry to finish his task, he wants to finish earlier than the other students. When he just want to start, one of his friends hides his pen. It was Wahyu who hide it, he was nosey Wahyu was hiding Rahmat's pen, he hides it in his pocket. Rahmat sees his act and complaining. The norm that applied in this conversation is the friendship norm. In this conversation, the relationship between Rahmat and Wahyu is a close friend.

When Rahmat express it his manner was serious. At the time he was peevish. The tone of his voice was normal, but his spirit was annoyed. He was in a hurry to finish his task. The information about this occurrence implies the researcher that they are in a serious conversation. This conversation is a close friend conversation in an annoying situation. According to discussions about the meaning, occurrence, and context above the researcher concludes that the intended meaning of term Asu in this expression is the same as its connotative meaning, which is "an obscene term used to describe an enraging situation." As the whole intended meaning of this expression, the researcher concludes that Rahmat was want to tell Wahyu that "i am in hurry, do not bother me."

\section{CONCLUSION}

In this study, the researcher found that the categorization of swearing words which contained in students' utterances are based on its literal or denotative meaning. The categories of expressed swearing words in this research are 1. One's Mother in Law (Sundala; Bitch); 2. Certain Game or Animal (Tolo; Bangsat; Goblok/Geblek; Anjing/Anjay/Anjir; Damn; Asu); 3. Sex/Copulative Term (Fuck); 4. Death (Setan); and 5. Excretion (Tai; Telaso; Shit).

As from the discussion about the intended meaning, the researcher found that the intended meaning of swearing words expressed by the student of SMA Negeri 1 
Makassar are mostly based on its connotative meaning. Most of them expressed swearing words in their conversation as the expression of startled and anger. Thus, the intended meaning of the expressions is as the normal response of what is being happened, for casual conversation.

\section{REFERENCES}

Crystal, David. 1995. The Cambridge Encyclopedia of The English Language. Cambridge: Cambridge University Press.

Feldman, Robert S. 1985. Social Psychology. Philadelphia: Ruttle, Shaw, and Wetherill, Inc.

Furchan, Ahmad. 2004. Pengantar Penelitian Dalam Pendidikan. Yogyakarta: Pustaka Pelajar.

Goodwin. (eds.). 1978. Rethinking Context: Language as an Interactive Phenomenon. Cambridge: Cambridge University Press.

H. Hoed, Benny. 2011. Semiotik dan Dinamika Sosial Budaya. Jakarta: Komunitas Bambu.

Hymes, D. H. 1974. Foundations in sociolinguistics: An ethnographic approach. Philadephia: University of Pennsylvania Press.

Levinson, Stephen C. 1985. Pragmatics. Cambridge: Cambridge University Press.

Thomas, Jenny. 1995. Meaning in Interaction: An Introduction to Pragmatics. London: Longman.

Wardhaugh, Ronald. 1986. An Introduction to Sociolinguistics. Malden, USA: Blackwell Publishing.

1998. An Introduction to Sociolinguistics (Third Edition). Malden, USA: Blackwell Publishing.

\section{Journal Article}

Sarah Sita Masykur, Purami. 2014. Bentuk dan Fungsi Umpatan Oleh Siswa SMA Negeri 2 Majene, Sulawesi Barat Dalam Situasi Nonformal. Jurnal Skriptorium, 64 (2), 63-75. 
Muh. Syaiful and Armin Harry Zainuddin

\section{Website}

https://en.wikipedia.org/

https://ielanguages.com/

https://www.urbandictionary.com/ 